Reducing pollution at five critical points of shale gas production:

Strategies and institutional responses

Terence J. Centner

Professor, College of Agricultural and Environmental Sciences

313 Conner Hall, The University of Georgia, Athens, GA 30602, USA

Tel.: 706-542-0756; email: tcentner@uga.edu 


\title{
Reducing pollution at five critical points of shale gas production: Strategies and institutional responses
}

\begin{abstract}
While the public and governments debate the advisability of engaging in shale gas production, the United States has proceeded to develop its resources with an accompanying remarkable increase in natural gas production. The development of shale gas has not been without problems, and some countries have decided that shale gas production should not proceed until more is known about the accompanying health issues and environmental damages. From experiences in the United States, careful consideration of five critical points relating to shale gas production can form the basis for developing strategies for reducing discharges of pollutants. For each strategy, institutional responses to markedly reduce the risks of harm to people and the environment are identified. These responses offer state and local governments ideas for enabling shale gas resources to be developed without sacrificing public health and environmental quality.
\end{abstract}

Keywords: air emissions, pollutants, shale gas

\section{Introduction}

Considerable public opposition exists to the deployment of hydraulic fracturing technologies used to recover unconventional oil and gas reserves (Clarke et al., 2015). In the 
United States, the petroleum industry has been successful in overcoming the opposition in most areas of the country so that the country is a major producer of shale gas. At the same time, some U.S. municipal governments and a few state governments have banned shale gas development (Nolon and Gavin, 2013). In Europe, the opposition to shale gas development is stronger (Upham et al., 2015). While there are a number of reasons for public opposition, the main focus is on people's health and the environment. The public is not convinced that introductions of toxic chemicals into their communities and releases of harmful emissions into the air are safe (Rawlins, 2014). Unfortunate mishaps have contributed to the public's concerns (Healy, 2013).

Governments, regulators, and business firms are aware of the public's concerns and have taken many efforts to address them and to minimize pollution (Wiseman, 2014). However, there are different opinions on how governments should address these concerns (Sovacool, 2014). Some feel that given the world's thirst for energy, we need to tap this energy source (Melikoglu, 2014). Another viewpoint is that using natural gas can be part of a stepwise transition toward the adoption of more sustainable materials and sources of energy (McFarland, 2012). Others feel that the world should be transitioning to renewable energy (Abas et al., 2015). Research suggests that cheap gas may displace renewables in countries under pressure to ensure energy supplies (Aguirre and Ibikunle, 2014; Kerr, 2010).

As the world continues to extract more shale gas, the real question is whether governments are doing enough to prevent damages, both to current and future populations. A significant body of research suggests that too many pollutants are being released from shale gas development (Eaton, 2013; Soeder et al., 2014; Wang et al., 2014; Werner et al., 2015). Yet the experiences of early adopters disclose five critical points during shale gas development for which regulatory controls can be employed to minimize environmental and health risks: (1) casing and 
cementing, (2) handling wastewater, (3) venting and flaring, (4) equipment with air emissions, and (5) seismic events. The five critical points were identified from reports of contamination, health maladies, and anticipated degradation associated with shale gas development and the feasibility of instituting responses that would alleviate some of the damages.

With the identification of these critical points, governments can develop strategies to deal with the use of hazardous chemicals in hydraulic fracturing and the release of harmful pollutants. For each strategy, ideas and specialized regulatory provisions are enumerated to provide energy firms and governments examples of how to structure operations to offer greater protection for the health of nearby residents and to maintain the quality of air and water resources. These institutional responses enable governments to establish safeguards that would protect people and the environment from egregious pollution that may accompany shale gas development.

\section{Enumerating five critical points}

A wide range of issues and problems have been associated with the development of America's shale gas resources. Highlighting five critical points identifies prominent sources of pollutants that can be reduced by adopting strategies implemented through institutional responses.

\subsection{Casing and cementing}

A major concern has been deleterious material leaking from shale gas wells, and many of these problems are associated with faulty casing and cementing. A study from Pennsylvania found that 3.3 percent of violations involved casing and cementing (Considine et al., 2013). 
Many persons with water wells in proximity to shale gas wells have complained about contaminated water from fracturing fluids (Brantley et al., 2014). Research from the United States shows methane contamination of aquifers (Osborn et al., 2011; Vengosh et al., 2013). One study showed the concentration of methane in drinking water was related to the distance to a shale gas well and that distance was the dominant statistical factor in these concentrations (Jackson et al., 2013).

Since shale gas in the United States is generally located 1500-2500 meters underground, layers of rock strata prevent leakage of contaminants into an aquifer. This suggests that contamination of groundwater should not be a problem unless the wellbore is faulty. Fugitive gas contamination problems are related to poor casing and cementing (Darrah et al., 2014). Research indicates gas migration as occurring after the conclusion of cementing jobs during the transition from slurry to solid cement (Soeder et al., 2014). In addition, faulty casings or cementing of wells can allow gases to migrate to drinking water supplies (Davies et al., 2014). This leads to a conclusion that greater oversight of wellbore integrity involving casing and cementing requirements can reduce contamination problems (Osborn et al., 2011; Jackson, 2014).

\subsection{Handling wastewater}

The public is rightfully concerned about water pollution from fracturing fluids, flowback, and produced water. Some feel that U.S. state enforcement efforts are not very robust, violators are rarely penalized, and penalties are so weak that drilling firms find it cheaper to pay occasional penalties rather than comply with the law (Sumi, 2012). Because fluids used to fracture wells generally contain toxic substances, and the fluids exiting a well may contain additional toxic materials from the rock strata, these liquids must be handled carefully (Vengosh 
et al., 2014; Vidic et al., 2013; Werner et al., 2015). Vehicular accidents and faulty storage structures may result in the release of toxic materials (Vinciguerra et al., 2015). Given the potent concentrations of selected toxic chemicals, a small spill or leak can have pronounced affects.

Although difficult to calculate, spills and releases of toxic substances associated with oil and gas wells are thought to be between 0.4 and 12.2 spills per 100 wells drilled (U.S. EPA, 2015a). One study suggests that about 3.4 percent of wells received notices of violations for well construction problems (Brantley et al., 2014). This suggests that efforts to reduce accidents and contain spills are important.

Related to these contamination events is the secrecy of chemical compounds used in hydraulic fracturing. Under U.S. state law, firms can decline to specifically identify any toxic compound that they feel is a trade secret (Centner, 2013; Hall, 2013). The U.S. EPA (2015b) estimates that $11 \%$ of all ingredient records were designated as confidential business information, and other research found considerable nondisclosure of all compounds used in fracturing wells (Konschnik and Dayalu, 2016). This creates a situation in which persons may not realize their health maladies are related to a pollutant release from shale gas development. Given the pollutant releases, spills, and accidents that have accompanied shale gas development in the United States, drilling firms may need to make greater investments in suitable precautionary measures to avoid accidents and mishaps. Simultaneously, governments can do more to address damages from contamination events.

\subsection{Venting and flaring}

Major air pollutants accompanying shale gas extraction are often released from the venting and flaring of methane and other gases at individual wells. These emissions generally 
consist of numerous pollutants including cancer-causing benzene (Witter et al., 2008). The releases are also related to the development of ozone (Werner et al., 2015). Gases are vented or flared because the costs of collecting them are prohibitive. The U.S. Energy Information Service estimates that more than 288,743 million cubic feet of gas were vented and flared from oil and gas wells in 2014 (U.S. Energy Information Administration, 2014). Global efforts to reduce gas flaring and venting through the evaluation of alternatives show significant opportunities for greenhouse gas emission reductions (Johnson and Coderre, 2012).

In the United States, new federal emissions standards to limit some releases of gases from shale gas wells were introduced in 2012 (U.S. EPA, 2012). The rules prescribe requirements for a separator to recover gas from flowback and route it to a beneficial use (U.S. EPA, 2014b). If it is not put to a useful purpose, the gas must be combusted (U.S. EPA, 2014b). These rules help minimize vented gas during a well completion and reduce air emissions. However, they only apply to new gas wells and some activities of refractured wells. Refractured wells that are not modified may continue to emit air pollutants (U.S. CFR, 2015, $\S \S 60.5365,60.5375$ ).

Moreover, wells producing oil, including some wells that produce both oil and gas, are exempted (U.S. EPA, 2012). It is estimated that one-half of new oil wells co-produce natural gas that may be flared or vented (U.S. EPA, 2014c). Excessive air emissions from venting and flaring remain a problem suggesting that governments need to find ways to be more effective in curtailing these pollutants.

\subsection{Equipment with air emissions}

Equipment and equipment failures can lead to unnecessary air pollutants being released during shale gas development that adversely affect health and contribute to global warming 
(Heath et al., 2014; Renjin and Zhenjie, 2015). The U.S. Environmental Protection Agency lists several harmful pollutants being emitted from shale gas development including benzene, toluene, ethylbenzene, xylenes, criteria pollutants, ozone precursors such as nitrous oxides and volatile organic compounds, and methane (U.S. EPA, 2013). The most obvious concern is the release of methane, as it has a global warming potential of 28-34 times that of carbon dioxide over a 100year time frame (Moore et al., 2014). The leakage of methane from production to final usage is estimated to be 2.8 percent of the U.S. domestic natural gas production (Moore et al., 2014). From a perspective of greenhouse gas emissions, the leakage is equivalent to about 155 million metric tons of $\mathrm{CO}_{2}$ (U.S. Department of Energy, 2015). Diesel engines, process heaters, combustors, treaters, dehydrators, condensate tanks, and pneumatic devices used in the development and transport of natural gas also emit considerable emissions (U.S. EPA, 2013, 2014a; Warneke et al., 2014).

Research studies have analyzed the presence of air emissions from shale gas wells to conclude that shale gas wells are subjecting people to harmful levels of air pollutants (Colborn et al., 2011; Meng, 2015). Due to the absence of data, research studies claiming shale gas development emissions are within acceptable air quality levels fail to account for combinations of emissions not covered by federal and state health-based air values and long-term exposure affects that are harmful (Werner et al., 2015). In addition to harming people, releases of greenhouse gases adversely affect the environment. U.S. federal regulations enunciate source performance standards that limit volatile organic compound emissions during well completion by requiring the use of reduced emissions completions, also known as "green completions," in qualifying situations (U.S. EPA, 2014b), but more protection for people's health is needed. 


\subsection{Seismic events}

Seismic events related to shale gas development and the disposal of wastes have garnered public attention and warrant further government oversight. Initially, searching for shale gas is often accompanied by seismic exploration searching for drilling prospects. These field tests help confirm the validity of drilling for gas. While they do not create major seismic shocks, they may cause damage to neighboring properties.

In developing wells, injecting fluids change the stress conditions around faults that may cause an earthquake by promoting slip on the fault (Council of Canadian Academies, 2014; National Research Council, 2012). Research in Texas and Oklahoma observed regional tectonic stresses and concluded that injection wells for wastewater and produced water from fracturing were the causes (Frohlich, 2012; Rubenstein and Mahani, 2015; Weingarten et al., 2015). Injection wells in other states have been linked to seismic activity (Frohlich, 2012).

In addition, research suggests that the extraction of fluids from oil and gas wells can cause seismic events (Frohlich and Brunt, 2013; van der Voort and Vanclay, 2015). Thus, it's the removal of underground hydrocarbons rather than fracturing that leads to the seismic activity, but this is immaterial since the public relates fracturing to the seismic activities that follow shale gas extraction. Moreover, although the risk of a major seismic event from hydraulic fracturing is low, the risk of seismic events can be minimized (Council of Canadian Academies, 2014; National Research Council, 2012). Careful site selection, monitoring, and reducing extraction rates can help alleviate problems. In some cases, it might be desirable to curtail extraction in wells closest to municipalities suffering from seismic activity (van der Voort and Vanclay, 2015). 


\section{Discussion and potential responses}

The absence of meaningful oversight of shale gas extraction activities by the U.S. federal government meant that state governments had to become more vigilant in protecting their citizens from health and environmental damages. The American experiences show that limitations imposed by democracy, division of powers among levels of governments, and economic challenges imposed by the 2008 financial crisis contributed to inadequate governmental responses. Over the past few years, citizens have petitioned governments to reduce externalities accompanying shale gas development and U.S. state governments have taken steps to provide greater protection for public health.

The identification of five critical points from which too many pollutants are discharged enables governments to address definitive pollution issues with strategies geared toward achieving reductions of pollutant releases. Moreover, industry can evaluate strategies and become more proactive in developing mechanisms to protect the public and the environment from damages. For each of the five critical points, two or more strategies are identified for responding to unnecessary discharges of pollutants and institutional responses are presented to assist governments in meeting their responsibilities in protecting people and the environment (Tables 1-4).

\subsection{Reducing damages from casing and cementing}

While most governments have already set out fairly comprehensive regulations that are appropriate for ensuring quality casing and cementing (Illinois Hydraulic Fracturing Regulatory Act, 2013), they may be able to do more by enacting, overseeing, and enforcing additional 
cementing and casing regulations to protect drinking water supplies (Table 1). Specialized

provisions can mandate more strict regulation, such as compliance with American Petroleum

Institute standards, so that firms cannot legally engage in lesser practices. In placing

responsibilities on drilling operators, Texas mandates the use of best currently available

technology for some situations and that all potentially productive zones be isolated and sealed off (Texas Administrative Code, 2016).

Two funding ideas are being employed to respond to casing and cementing problems (Dana and Wiseman, 2014). State law can require drilling firms to have mandatory insurance liability coverage. A requirement for restoration bonds can collect funds for subsequent use in restoring damaged environments.

Another idea to address potential water pollution from faulty casing and cementing is to adopt a legislative provision establishing a presumption on liability for new wells being drilled. In Pennsylvania, the legislature adopted a presumption that pollution of water near new oil or gas well within a time frame is presumed to come from drilling the oil or gas well (Pennsylvania Consolidated Statutes, 2016). These ideas show that, through more comprehensive provisions assigning responsibilities and liability, governments can help firms further reduce contamination events and damages related to faulty cementing and casing.

\subsection{Reducing damages from wastewater}

More exacting regulatory provisions can lead firms engaged in drilling activities to take actions that should reduce contamination events and damages from wastewater (Table 2). One major proposal to facilitate timely responses to exposure to hazards is greater disclosure of the chemical compounds used at a well site. In 2015, the U.S. federal Bureau of Land Management 
adopted a regulation to limit the non-disclosure of chemical compounds used at wells on federal lands (U.S. CFR, 2015). While the listed details of this regulation do not require disclosure of all compounds, a person will need to sign the affidavit justifying non-disclosure. This may encourage firms to release additional information.

A second idea to reduce damages from wastewater is to allow local governments to enact controls they feel are necessary to protect their citizens. Local governments were formed to enable citizens to address matters of local concern and may be in the best position to quickly respond to a problem (Centner and Kostandini, 2015). U.S. state governments should not be preempting local controls as has occurred in New York and Ohio (New York Environmental Conservation Law, 2015; Ohio Revised Code Annotated, 2015).

Third, a certification program may be adopted with a provision that precludes discharges of wastewater. The certification program offered by the Center for Sustainable Shale Development (2015) precludes direct or indirect intentional discharges of shale wastewater to surface water except as provided by their standard (Table 2). Another idea is to increase severance tax collections and use the funds to respond to negative externalities (Rabe and Hampton, 2015). Governments can select the recipients of the funds to address those issues most worthy of financial assistance (Colorado Revised Statutes, 2015).

\subsection{Venting and flaring strategies}

Governments have a number of options to pursue in reducing gases that are released during well drilling and limiting their adverse environmental effects (Table 3). An initial strategy is to require the recovery of gases rather than allowing them to be vented or flared (Rahimpour and Jokar, 2012). Recovery may involve the collection and compression of gas into pipelines for 
processing and sale, the generation of electricity, or the re-injection of the gas back into an underground reservoir (Johnson and Coderre, 2012). The adoption of reduced emission completions by the U.S. EPA should reduce emissions of pollutants, but too many exceptions allow excessive releases of air pollutants (U.S. EPA, 2014c).

To further reduce amounts of pollutants entering the atmosphere in situations where recovery is difficult or expensive, governments can limit the situations in which gases are vented by requiring they be flared (Texas Administrative Code, 2016). An additional possibility is a regulation that bans venting except for emergencies (Table 3).

Limitations on flaring are also needed. Governments may adopt a regulation enumerating a policy that flaring wastes resources and should only be used when no feasible recovery system is possible. The number of days that flaring is allowed at a well may be established by a regulation. Because certain types of releases are more dangerous than others, governments can also limit the release of certain pollutants (Table 3). A possibility under this option is to place requirements on the flaring equipment so that fewer pollutants enter the atmosphere (U.S. EPA, 2014c; U.S. Department of the Interior, 2016). The implementation of a third-party certification specifying additional practices to reduce emissions may also enhance air quality.

\subsection{Equipment with air emissions strategies}

Due to leaks and other problems with equipment used to transport gas to market, governments can adopt strategies to reduce the pollutants emitted (U.S. EPA, 2014b). Two strategies are to adopt a limit on the estimated amounts of gas being lost and require firms releasing emissions to report their releases (Table 1). The U.S. EPA is proposing to require that owners and operators of oil well sites use a technology known as optical gas imaging to conduct 
a leak monitoring survey. Optical gas imaging equipment uses a special camera to "see"

emissions of methane and volatile organic compounds (EPA, 2015c). Specifications on equipment can be implemented to reduce air pollutants.

\subsection{Seismic events strategies}

To address seismic exploration for hydrocarbon reserves, a government may require a seismic operations permit and a restoration bond (Table 1). However, the major concerns involve seismic events related to the injection of fluids or removal of hydrocarbons. Governments may want to adopt more strict siting requirements relating to faults. In addition, they might implement insurance programs funded by taxes collected on produced hydrocarbons to provide monies to property owners who experience damages (Rabe, 2014).

\section{Conclusion and policy implications}

Although the development of shale gas resources has proven controversial, it is not that different from other new technologies that are accompanied by significant health and environmental risks. Governments lag in developing needed health and safety regulations, accidents and difficulties occur, but eventually an acceptable balance is reached that allows the adoption of the technology despite accompanying problems. Given the health dangers and environmental risk that accompany shale gas development, governmental regulations are needed. Yet, while others can learn from the U.S. experiences, what has transpired in the United States may not be an accurate reference for validating the performance of shale gas policies in other countries (Lozano Maya, 2013). 


\section{Acknowledgment}

The research is based on work supported by the Cooperative State Research Education and Extension Service, U.S. Department of Agriculture Project No. GEO00684. The funding source had no involvement in overseeing the research.

\section{References}

Abas, N., Kalair, A., Khan, N., 2015. Review of fossil fuels and future energy technologies. Futures 69, 31-49.

Aguirre, M., Ibikunle, G., 2104. Determinants of renewable energy growth: A global sample 
analysis. Energy Policy 69, 374-384.

Brantley, S.L., Yoxtheimer, D., Arjmand, S., Grieve, P., Vidic, R., Pollak, J., Llewellyn, G.T., Abad, J., Simon, C., 2014. Water resource impacts during unconventional shale gas development: The Pennsylvania experience. Int. J. Coal Geol. 126, 140-156.

California Code of Regulations, 2015. Title 17, section 95153.

Center for Sustainable Shale Development, 2013. Performance Standards. Pittsburgh, PA. https://www.sustainableshale.org/wp-content/uploads/2014/06/CSSD_PerformanceStandards-v.-1.2.pdf (accessed 23 February 2016).

Center for Sustainable Shale Development, 2015. Performance Standards and Regulatory Standards Across the Appalachian Basin. Pittsburgh, PA. https://www.sustainableshale.org/wp-content/uploads/2015/03/CSSD-COMPARISONTABLE-3.1.15.pdf (accessed 23 February 2016).

Centner, T.J., 2013. Oversight of shale gas production in the United States and the disclosure of toxic substances. Resour. Policy 38, 233-240.

Centner, T.J., Kostandini, G., 2015. Local governments want authority to address problems: The case of horizontal drilling and hydraulic fracturing in the United States. Land Use Policy 49, 7-235.

Centner, T.J., Petetin, L., 2015. Permitting program with best management practices for shale gas wells to safeguard public health. J. Environ. Manage. 163, 174-183.

Clarke, C.E., Hart, P.S., Schuldt, J.P., Evensen, D.T.N., Boudet, H.S., Jacquet, J.B., Stedman, R.C., 2015. Public opinion on energy development: The interplay of issue framing, topof-mind associations, and political ideology. Energy Policy 81, 131-140.

Colborn, T., Kwiatkowski, C., Schultz, K., Bachran, M., 2011. Natural gas operations from a 
public health perspective. Hum. Ecol. Risk Assess. 17, 1039-1056.

Colorado Revised Statutes, 2015. Sections 39-29-109, 39-29-110.

Considine, T.J., Watson, R.W., Considine, N.B., Martin, J.P., 2013. Environmental regulation and compliance of Marcellus Shale gas drilling. Environ. Geosci. 20, 1-16.

Council of Canadian Academies, 2014. Environmental Impacts of Shale Gas Extraction in Canada. Council of Canadian Academies, Ottawa, Canada. http://www.scienceadvice.ca/uploads/eng/assessments\%20and\%20publications\%20and\% 20news\%20releases/shale\%20gas/shalegas_fullreporten.pdf (accessed 23 February 2016).

Dana, D.A., Wiseman, H.J., 2014. A market approach to regulating the energy revolution: Assurance bonds, insurance, and the certain and uncertain risks of hydraulic fracturing. Iowa Law Rev. 999, 1523-1593.

Darrah, T.H., Vengosh, A., Jackson, R.B., Warner, N.R., Poreda, R.J., 2014. Noble gases identify the mechanisms of fugitive gas contamination in drinking-water wells overlying the Marcellus and Barnett Shales. Proc. Natl. Acad. Sci. USA 111 (39), 14076-14081.

Davies, R.J., Almond, S., Ward, R.S., Jackson, R.B., Adams, C., Worrall, F., Harringshaw, L.G., Gluyas, J.G., Whitehead, M.A., 2014. Oil and gas wells and their integrity: Implications for shale and unconventional resource exploitation. Mar. Pet. Geol. 56, 239-254.

Eaton, T.T., 2013. Science-based decision-making on complex issues: Marcellus Shale gas hydrofracturing and New York City water supply. Sci. Total Environ. 461-462, 158-169.

Frohlich, C., 2012. Two-year survey comparing earthquake activity and injection-well locations in the Barnett Shale, Texas. Proc. Natl. Acad. Sci. USA 109, 13934-13938.

Frohlich, C., Brunt, M., 2013. Two-year survey of earthquakes and injection/production wells in 
the Eagle Ford Shale, Texas, prior to the $\mathrm{M}_{\mathrm{W}} 4.820$ October 2011 earthquake. Earth Planet. Sci. Lett. 379, 56-63.

Hall, K.B., 2013. Hydraulic fracturing: Trade secrets and the mandatory disclosure of fracturing water composition. Idaho Law Rev. 49, 399-435.

Healy, J., 2013. After the floods in Colorado, a deluge of worry about leaking oil. New York Times 27 September 2013, sec. A, p. 12.

Heath, G., Meldrum, J., Fisher, N., Arent, D., Bazilian, M., 2014. Life cycle greenhouse gas emissions from Barnett Shale gas used to generate electricity. J. Unconvent. Oil Gas Resour. 8, 46-55.

Illinois Compiled Statutes Annotated, 2016. Chapter 225, sections 732/1-35, 732/1-70.

Illinois Hydraulic Fracturing Regulatory Act, 2013. Public Act 098-0022.

Ismail, O.S., Umukoro, G.E., 2012. Global impact of gas flaring. Energy \& Power Engineer. 4, 290-302.

Jackson, R.B., 2014. The integrity of oil and gas wells. Proc. Natl. Acad. Sci. USA 111, $10902-$ 10903.

Jackson, R.B, Vengosh, A., Darrah, T.H., Warner, N.R., Down, A., Poreda, R.J., Osborn, S.G., Zhao, K., Karr, J.D., 2013. Increased stray gas abundance in a subset of drinking water wells near Marcellus shale gas extraction. Proc. Natl. Acad. Sci. USA 110, 11250-11255.

Johnson, M.R., Coderre, A.R., 2012. Opportunities for CO2 equivalent emissions reductions via flare and vent mitigation: A case study for Alberta, Canada. Int. J. Greenhouse Gas Control 8, 121-131.

Kerr, R.A., 2010. Natural gas from shale bursts onto the scene. Science 328, 1624-1626.

Konschnik, K., Dayalu, A., 2016. Hydraulic fracturing chemicals reporting: Analysis of available 
data and recommendations for policymakers. Energy Policy 88, 504-514.

Lozano Maya, J.R., 2013. The United States experience as a reference of success for shale gas development: The case of Mexico. Energy Policy 62, 70-78.

McFarland, E., 2012. Unconventional chemistry for unconventional natural gas. Science 338, 340-343.

Melikoglu, M., 2014. Shale gas: Analysis of its role in the global energy market. Renew. Sustain. Energy Rev. 37, 460-468.

Meng, Q., 2015. Spatial analysis of environment and population at risk of natural gas fracking in the state of Pennsylvania, USA. Sci. Total Environ. 515-516, 198-206.

Moore, C.W., Zielinska, B., Pétron, G., Jackson, R.B., 2014. Air impacts of increased natural gas acquisition, processing, and use: A critical review. Environ. Sci. Technol. 48, 8349-8359.

National Research Council, 2012. Induced Seismicity Potential in Energy Technologies. National Academy Press, Washington, DC.

New York Environmental Conservation Law, 2015. Section 23-0303.

Nolon, J.R., Gavin, S.E., 2013. Hydrofracking: State preemption, local power, and cooperative governance. Case Western Reserve Law Rev. 63, 995-1038.

North Carolina General Statutes, 2015. Sections 113-378, 113-391.

North Dakota Administrative Code, 2015. Section 33-15-20-03.

Ohio Administrative Code, 2015. Sections 1501:9-3-06, 3701:1-54-09.

Ohio Revised Code Annotated, 2015. Sections 1509.02, 1509.07.

Oklahoma Administrative Code, 2014. Sections 165:5-7-27, 165:10-5-5.

Oklahoma Statutes Annotated, 2015. Title 52, sections 318.22, 318.23.

Osborn, S.G., Vengosh, A., Warner, N.R., Jackson, R.B., 2011. Methane contamination of 
drinking water accompanying gas-well drilling and hydraulic fracturing. Proc. Natl.

Acad. Sci. USA 108, 8172-8176.

Pennsylvania Consolidated Statutes. 2016. Title 58, section 3218.

Rabe, B.G., 2014. Shale play politics: The intergovernmental odyssey of American shale governance. Environ. Sci. Tech. 48, 8369-8375.

Rabe, B.G., Hampton, R.L., 2015. Taxing fracking: The politics of state severance taxes in the shale era. Rev. Policy Res. 32, 389-412.

Rahimpour, M.R., Jokar, S.M., 2012. Feasibility of flare gas reformation to practical energy in Farashband gas refinery: No gas flaring. J. Hazard. Materials 209-210, 204-217.

Rawlins, R., 2014. Planning for fracking on the Barnett shale: Soil and water contamination concerns, and the role of local government. Environ. Law 44, 135-199.

Renjin, S., Zhenjie W., 2015. A comprehensive environmental impact assessment method for shale gas development. Natur. Gas Industry B 2, 203-210.

Rubenstein, J.L., Mahani, A.B., 2015. Myths and facts on wastewater injection, hydraulic fracturing, enhanced oil recovery, and induced seismicity. Seismolog. Res. Lett. 86 (4), doi: $10.1785 / 0220150067$.

Soeder, D.J., Sharma, S., Pekney, N., Hopkinson, L., Dilmore, R., Kutchko, B., Stewart, B., Carter, K., Hakala, A., Capo, R., 2014. An approach for assessing engineering risk from shale gas wells in the United States. Int. J. Coal Geol. 126, 4-19.

Sovacool, B.K., 2014. Cornucopia or curse? Reviewing the costs and benefits of shale gas hydraulic fracturing (fracking). Renew. Sustain. Energy Rev. 37, 249-264.

Sumi, L., 2012. Breaking All the Rules: The Crisis in Oil and Gas Regulatory Enforcement. Earthworks’ Oil and Gas Accountability Project. Earthworks, Washington, DC. 
Texas Administrative Code, 2016. Title 16, sections 3.13, 3.32, 3.46, 3.9; title 30, section 106.352.

U.S. CFR (Code of Federal Regulations), 2015. Title 40, §§ 60.5365, 60.5375; title 43, § 3162.33.

U.S. Department of Energy, 2015. Quadrennial Energy Review: Energy Transmission, Storage, and Distribution Infrastructure, Chapter VII, Addressing Environmental Aspects of TS\&D Infrastructure, April 2015, Washington, DC. http://energy.gov/epsa/downloads/quadrennial-energy-review-full-report (accessed 23 February 2016).

U.S. Department of the Interior, 2016. Environmental Assessment: Waste Prevention, Production Subject to Royalties, and Resource Conservation. DOI-BLM-WO310-2015-XXX-EA, 22 January 2016.

U.S. EPA (Environmental Protection Agency), 2012. Oil and natural gas sector: New source performance standards and national emission standards for hazardous air pollutants reviews. Federal Register 77 (159), 49490-49600.

U.S. EPA, 2013. EPA Needs to Improve Air Emissions Data for the Oil and Natural Gas Production Sector. Report No. 13-P-0161. EPA Office of Inspector General, Washington, DC.

U.S. EPA, 2014a. Oil and Natural Gas Sector Leaks. April 2014. EPA Office of Air Quality Planning and Standards, Washington, DC. http://www.epa.gov/airquality/oilandgas/2014papers/20140415leaks.pdf (accessed 23 February 2016).

U.S. EPA, 2014b. Oil and natural gas sector: Reconsideration of additional provisions of new 
source performance standards, part III. Federal Register 79 (250), 79018-79041.

U.S. EPA, 2014c. Oil and natural gas sector hydraulically fractured oil well completions and associated gas during ongoing production. April 2014. EPA Office of Air Quality Planning and Standards, Washington, DC. http://www.epa.gov/airquality/oilandgas/2014papers/20140415completions.pdf (accessed 23 February 2016).

U.S. EPA, 2015a. Assessment of the Potential Impacts of Hydraulic Fracturing for Oil and Gas on Drinking Water Resources (External Review Draft), EPA/600/R-15/047a, June 2015, Washington, DC. http://cfpub.epa.gov/ncea/hfstudy/recordisplay.cfm?deid=244651 (accessed 23 February 2016).

U.S. EPA, 2015b. Analysis of Hydraulic Fracturing Data from the FracFocus Disclosure Registry 1.0. EPA/601/R-14/003, March 2015.

U.S. EPA, 2015c. Control Techniques Guidelines for the Oil and Natural Gas Industry (Draft). EPA-453/P-15-001, August 2015.

U.S. Energy Information Administration, 2014. Natural Gas Gross Withdrawals and Production, Data Series: Vented and Flared for 2013, Washington, DC. http://www.eia.gov/dnav/ng/ng_prod_sum_a_EPG0_VGV_mmcf_a.htm (accessed 23 February 2016).

Upham, P., Lis, A.L., Riesch, H., Stankiewicz, P., 2015. Addressing social representations in socio-technical transitions with the case of shale gas. Environ. Innov. Societal Transitions $16,120-141$.

Utah Administrative Code, 2015. Rule R649-3-20.

van der Voort, N., Vanclay, F., 2015. Social impacts of earthquakes caused by gas extraction in 
the Province of Groningen, The Netherlands. Environ. Impact Assess. Rev. 50, 1-15.

Vengosh, A., Jackson, R.B., Warner, N., Darrah, T.H., Kondash, A., 2014. A critical review of the risks to water resources from unconventional shale gas development and hydraulic fracturing in the United States. Environ. Sci. Technol. 48, 8334-8348.

Vengosh, A., Warner, N., Jackson, R., Darrah., T., 2013. The effects of shale gas exploration and hydraulic fracturing on the quality of water resources in the United States. Procedia Earth Planetary Sci. 7, 863-866.

Vidic, R.D., Brantley, S.L., Vandenbossche, J.M., Yoxtheimer, D., Abad, J.D., 2013. Impact of shale gas development on regional water quality. Science 340, 826-835.

Vinciguerra, T., Yao, S., Dadzie, J., Chittams, A., Deskins, T., Ehrman, S., Dickerson, R.R., 2015. Regional air quality impacts of hydraulic fracturing and shale natural gas activity: Evidence from ambient VOC observations. Atmos. Environ. 110, 144-150.

Wang, Q., Chen, X., Jha, A.N., Rogers, H., 2014. Natural gas from shale formation - the evolution, evidences and challenges of shale gas revolution in United States. Renew. Sustain. Energy Rev. 30, 1-28.

Warneke, C., Geiger, F., Edwards, P.M., Dube, W., Pétron, G., Kofler, J., Zahn, A., Brown, S.S., Graus, M., Gilman, J.B., Lerner, B.M., Peischl, J., Ryerson, T.B., de Gouw, J.A., Roberts, J.M., 2014. Volatile organic compound emissions from the oil and natural gas industry in the Uintah Basin, Utah: Oil and gas well pad emissions compared to ambient air composition. Atmos. Chem. Physics 14, 10977-10988.

Weingarten, M., Ge, S., Godt, J.W., Bekins, B.A., Rubinstein, L., 2015. High-rate injection is associated with the increase in U.S. mid-continent seismicity. Science 348, 1336-1340.

Wells, B., 2014. Please give us one more oil boom-I promise not to screw it up this time: The 
broken promise of casinghead gas flaring in the Eagle Ford Shale. Texas J. Oil, Gas, \& Energy Law 9, 319-355.

Werner, A.K., Vink, S., Watt, K., Jagals, P., 2015. Environmental health impacts of unconventional natural gas development: A review of the current strength of evidence. Sci. Total Environ. 505, 1127-1141.

West Virginia Code, 2016. Sections 22-6-35, 22-6A-18.

Wiseman, H.J., 2014. Regulatory islands. New York Univ. Law Rev. 89, 1661-1742.

Witter, R., Stinson, K., Sackett, H., Putter, S., Kinney, G., Teitelbaum, D., Newman, L., 2008. Potential exposure related human health effects of oil and gas development: A literature review (2003-2008). Colorado School of Public Health, Denver, CO. 
Table 1. Strategies to reduce discharges from casing and cementing.

\begin{tabular}{|c|c|c|}
\hline Strategy & Sources of strategies & Adapted specialized provisions \\
\hline \multirow[t]{3}{*}{ Strict regulations } & $\begin{array}{l}\text { Illinois Compiled Statutes } \\
\text { Annotated ch. } 225, \S 732 / 1-70\end{array}$ & Meet American Petroleum Institute standards. \\
\hline & \multirow{2}{*}{$\begin{array}{l}\text { Texas Administrative Rules } \\
\text { tit. } 16, \S 3.13\end{array}$} & Use best currently available technology for non-detailed specific methods. \\
\hline & & $\begin{array}{l}\text { All usable-quality water zones be isolated and sealed off and all potentially } \\
\text { productive zones be isolated and sealed off. }\end{array}$ \\
\hline \multirow[t]{2}{*}{ Insurance coverage } & $\begin{array}{l}\text { Illinois Compiled Statutes } \\
\text { Annotated ch. } 225, \S 732 / 1-35\end{array}$ & $\begin{array}{l}\text { Every applicant for a permit shall provide proof of insurance to cover injuries, } \\
\text { damages, or loss related to pollution. }\end{array}$ \\
\hline & $\begin{array}{l}\text { Ohio Revised Code Annotated } \\
\S 1509.07\end{array}$ & $\begin{array}{l}\text { An owner of any well shall obtain liability insurance coverage in an amount of not } \\
\text { less than one million dollars. }\end{array}$ \\
\hline \multirow[t]{2}{*}{ Restoration bonds } & $\begin{array}{l}\text { North Carolina General } \\
\text { Statutes } \S 113-378\end{array}$ & $\begin{array}{l}\text { Before making any drilling exploration in this State for oil or natural gas, the person, } \\
\text { firm, or corporation shall file a bond. }\end{array}$ \\
\hline & $\begin{array}{l}\text { Ohio Revised Code Annotated } \\
\S 1509.07\end{array}$ & $\begin{array}{l}\text { Before operating or producing from a well, the owner shall execute and file a surety } \\
\text { bond conditioned on compliance with the restoration requirements. }\end{array}$ \\
\hline \multirow[t]{2}{*}{$\begin{array}{l}\text { Presumption of } \\
\text { liability }\end{array}$} & $\begin{array}{l}\text { Pennsylvania Consolidated } \\
\text { Statutes, tit. } 58, \S 3218\end{array}$ & $\begin{array}{l}\text { For an unconventional well, it shall be presumed that a well operator is responsible } \\
\text { for pollution if the water supply is within } 2,500 \text { feet of the unconventional vertical } \\
\text { well bore and the pollution occurred within } 12 \text { months. }\end{array}$ \\
\hline & $\begin{array}{l}\text { West Virginia Code } \\
\S \S 22-6-35,22-6 A-18\end{array}$ & $\begin{array}{l}\text { In any action for contamination of a fresh water source or supply within one } \\
\text { thousand feet of the site of drilling for an oil or gas well, there shall be a rebuttable } \\
\text { presumption that such drilling was the proximate cause of the contamination or } \\
\text { deprivation of such fresh water source or supply. }\end{array}$ \\
\hline
\end{tabular}




\section{Table 2. Strategies to reduce discharges from handling wastewater.}

\begin{tabular}{|c|c|c|}
\hline Strategy & Sources of strategies & Ideas and specialized provisions \\
\hline $\begin{array}{l}\text { Disclosure of } \\
\text { fracking fluids }\end{array}$ & $\begin{array}{l}\text { U.S. CFR, title } 43, \S 3162.3- \\
3\end{array}$ & $\begin{array}{l}\text { Disclose of the information claimed to be exempt from public disclosure needs to be } \\
\text { accompanied by an affidavit that affirms that the information is not publicly available, } \\
\text { affirms that the information is not required to be publicly disclosed, affirms that the owner of } \\
\text { the information is in actual competition, and affirms that the release of the information } \\
\text { would likely cause substantial competitive harm to the owner of the information. }\end{array}$ \\
\hline \multirow[t]{2}{*}{$\begin{array}{l}\text { No preemption } \\
\text { of local law }\end{array}$} & $\begin{array}{l}\text { Centner and Kostandini, } \\
2015\end{array}$ & $\begin{array}{l}\text { The derogation of local laws over negative externalities that accompany fracturing activities } \\
\text { may expose citizens to more risks and damages and lessen the quality of life of their citizens } \\
\text { and impose costs. }\end{array}$ \\
\hline & & $\begin{array}{l}\text { Local governments are especially valuable for serving as laboratories of experimentation in } \\
\text { achieving environmental goals. }\end{array}$ \\
\hline $\begin{array}{l}\text { Certification of } \\
\text { discharges }\end{array}$ & $\begin{array}{l}\text { Center for Sustainable Shale } \\
\text { Development, } 2013\end{array}$ & $\begin{array}{l}\text { Zero discharges to surface waters except through a permitted centralized waste treatment } \\
\text { facility with an effluent performance standard based on current best available technology. }\end{array}$ \\
\hline \multirow[t]{2}{*}{ Severance taxes } & $\begin{array}{l}\text { Colorado Revised Statutes } \\
\S \S 39-29-109,39-29-110\end{array}$ & $\begin{array}{l}\text { Funds to be distributed to those political subdivisions impacted by the development, } \\
\text { processing, or energy conversion of minerals and mineral fuels; funds for the development } \\
\text { and conservation of the state's water resources, use in funding programs related to minerals, } \\
\text { energy, geology, and water and for the use in funding programs to reduce the burden of } \\
\text { increasing home energy costs on low-income households. }\end{array}$ \\
\hline & Rabe and Hampton, 2015 & $\begin{array}{l}\text { Severance tax revenues can be used to respond to negative externalities and local } \\
\text { government needs linked to drilling operations. }\end{array}$ \\
\hline
\end{tabular}


Table 3. Strategies to reduce emissions from venting and flaring.

\begin{tabular}{|c|c|c|}
\hline Strategy & Sources of strategies & Ideas and specialized provisions \\
\hline Recovery & $\begin{array}{l}\text { U.S. EPA, 2014c; US CFR, } \\
2015\end{array}$ & $\begin{array}{l}\text { Ensure minimal emissions through reduced emissions completions and apply reduced } \\
\text { emissions completions to additional refractured wells and wells producing oil. }\end{array}$ \\
\hline \multirow[t]{2}{*}{ Limit venting } & $\begin{array}{l}\text { Texas Administrative Code } \\
\text { tit. } 16, \S 3.32\end{array}$ & Requiring flaring of gas releases rather than venting. \\
\hline & $\begin{array}{l}\text { U.S. Department of the } \\
\text { Interior, } 2016\end{array}$ & $\begin{array}{l}\text { Ban venting of gas except in certain specified circumstances (such as emergencies), and to } \\
\text { limit flaring of gas from such wells. }\end{array}$ \\
\hline \multirow[t]{3}{*}{ Limit flaring } & Wells, 2014 & $\begin{array}{l}\text { Adopt a regulation affirmatively stating that the flaring of casing-head gas from a well } \\
\text { represents "waste" that is not allowed except situations with extenuating circumstances.. }\end{array}$ \\
\hline & $\begin{array}{l}\text { Center for Sustainable Shale } \\
\text { Development, } 2013\end{array}$ & $\begin{array}{l}\text { Flaring may not be used for more than 14-days on any development well. Flaring may not } \\
\text { be used for more than 30-days on any exploratory or extension wells. }\end{array}$ \\
\hline & Ismail and Umukoro, 2012 & $\begin{array}{l}\text { Institute modeling and computerized program requirements to limit when and how gas is } \\
\text { flared. }\end{array}$ \\
\hline \multirow[t]{2}{*}{$\begin{array}{l}\text { Limits on } \\
\text { discharges }\end{array}$} & $\begin{array}{l}\text { North Dakota Administrative } \\
\text { Code } \S 33-15-20-03\end{array}$ & $\begin{array}{l}\text { Any well production facility emitting two hundred fifty tons per year or more of any air } \\
\text { contaminant shall comply with the permitting requirements. }\end{array}$ \\
\hline & $\begin{array}{l}\text { Utah Administrative Code } \\
\text { R649-3-20 }\end{array}$ & $\begin{array}{l}\text { Up to } 1,800 \text { thousand cubic feet of oil well gas may be vented or flared from an individual } \\
\text { well on a monthly basis at any time without approval. }\end{array}$ \\
\hline Certification & $\begin{array}{l}\text { Center for Sustainable Shale } \\
\text { Development, } 2013\end{array}$ & $\begin{array}{l}\text { Any gas not captured may not be vented and must be flared through raised/elevated flares } \\
\text { or an engineered combustion device with a reliable continuous ignition source, which have } \\
\text { at least a } 98 \% \text { destruction efficiency of methane; rules to minimize flaring and maximize } \\
\text { the use of reduced emissions completions on exploratory or extension wells. }\end{array}$ \\
\hline
\end{tabular}


Table 4. Additional strategies to reduce discharges from critical points.

\begin{tabular}{|c|c|c|c|}
\hline Critical point & Strategy & Sources of strategies & Ideas and specialized provisions \\
\hline \multirow[t]{4}{*}{$\begin{array}{l}\text { Equipment with } \\
\text { emissions }\end{array}$} & Limit gas loss & $\begin{array}{l}\text { Texas Administrative Code tit. } 30 \text {, } \\
\S 106.352\end{array}$ & $\begin{array}{l}\text { Facilities are permitted by rule unless total emissions exceed limits } \\
\text { expressed in tons per day. }\end{array}$ \\
\hline & $\begin{array}{l}\text { Reporting } \\
\text { emissions }\end{array}$ & $\begin{array}{l}\text { California Code of Regulations, } \\
\text { tit. } 17, \S 95153\end{array}$ & $\begin{array}{l}\text { The operator of a facility must calculate and report annual } \\
\text { greenhouse gas emissions as prescribed in this section. }\end{array}$ \\
\hline & $\begin{array}{l}\text { Reducing gas } \\
\text { leaks }\end{array}$ & US EPA, 2015c & $\begin{array}{l}\text { Require the use of equipment using a toxic vapor analyzer or } \\
\text { organic vapor analyzer; require the use a technology known as } \\
\text { optical gas imaging to conduct a leaks monitoring survey. }\end{array}$ \\
\hline & $\begin{array}{l}\text { Reducing } \\
\text { emissions }\end{array}$ & $\begin{array}{l}\text { Center for Sustainable Shale } \\
\text { Development, } 2013\end{array}$ & Non-road engine standards and emissions limitations. \\
\hline \multirow[t]{4}{*}{ Seismic events } & Exploration & $\begin{array}{l}\text { Oklahoma Statutes Annotated tit. } \\
\text { 52, } \S \S 318.22,318.23 \text {; Oklahoma } \\
\text { Administrative Code } § 165: 10-1-7\end{array}$ & $\begin{array}{l}\text { Permit and bonding requirements; owners entitled to damages } \\
\text { sustained by reason of the operator's seismic exploration. }\end{array}$ \\
\hline & Disposal wells & $\begin{array}{l}\text { Ohio Administrative Code } \S \S \\
\text { 1501:9-3-06, 3701:1-54-09 }\end{array}$ & $\begin{array}{l}\text { For brine injection wells, a geological investigation of potential } \\
\text { faulting within the immediate vicinity may be required; avoidance } \\
\text { of areas where tectonic processes may occur. }\end{array}$ \\
\hline & & $\begin{array}{l}\text { Oklahoma Administrative Code } \S \S \\
165: 5-7-27,165: 10-5-5\end{array}$ & $\begin{array}{l}\text { Required application with responsibilities for plugging and } \\
\text { reclaiming the site; surety requirement. }\end{array}$ \\
\hline & & $\begin{array}{l}\text { Texas Administrative Code tit. } 16 \text {, } \\
\S \S 3.46,3.9\end{array}$ & $\begin{array}{l}\text { Authority to modify, suspend, or terminate a disposal well permit } \\
\text { based on its contribution to seismic activity. }\end{array}$ \\
\hline
\end{tabular}

